AGNIESZKA WDOWIAK

Kielce University of Technology

e-mail: awdowiak@tu.kielce.pl

JANUSZ BROL

Silesian University of Technology

e-mail: janusz.brol@polsl.pl
Manuscript submitted 2019.10.16 - revised 2019.10.16, initially accepted for publication 2019.10.17, published in September 2019

\title{
METHODS OF STRENGTH GRADING OF STRUCTURAL TIMBER - COMPARATIVE ANALYSIS OF VISUAL AND MACHINE GRADING ON THE EXAMPLE OF SCOTS PINE TIMBER FROM FOUR NATURAL FOREST REGIONS OF POLAND
}

\author{
METODY SORTOWANIA WYTRZYMAŁOŚCIOWEGO TARCICY \\ KONSTRUKCYJNEJ - ANALIZA PORÓWNAWCZA SORTOWANIA \\ WIZUALNEGO I MASZYNOWEGO NA PRZYKŁADZIE POLSKIE
} TARCICY SOSNOWE Z CZTERECH KRAIN PRZYRODNICZO-LEŚNYCH

\author{
DOI: $10.30540 /$ sae-2019-016
}

\begin{abstract}
A b stract
The article covers the strength grading system methodology for construction timber. The presented analysis identified important issues concerning the verification of structural and geometric characteristics during construction timber strength grading by visual and machine method. The following considerations specified the guidelines for the classification of coniferous construction timber in sawmills. The paper also presents the results of the visual and machine classification performed for Scots pine timber from four natural forest regions of Poland. As a result of the conducted research it was stated that the use of machine classification equipment allows obtaining a larger amount of pine timber with better mechanical properties and eliminating the rejected timber.
\end{abstract}

Keywords: construction timber, strength grading, visual method, machine method, wood defects, structural and geometric characteristics

\section{Streszczenie}

Artykut obejmuje metodyke sortowania wytrzymałościowego tarcicy konstrukcyjnej. Przedstawiona analiza określiła ważne zagadnienia dotyczące weryfikacji cech strukturalnych i geometrycznych $w$ trakcie sortowania wytrzymałościowego tarcicy konstrukcyjnej metoda wizualna oraz metoda maszynowa. Poniższe rozważania skonkretyzowaty wytyczne stużące klasyfikacji tarcicy konstrukcyjnej iglastej w tartakach. W pracy ukazano również wyniki badań klasyfikacji wizualnej i maszynowej sosnowej tarcicy konstrukcyjnej pochodzacej z czterech krain przyrodniczo-leśnych Polski. W efekcie przeprowadzonych badań stwierdzono, że wykorzystanie urządzen do klasyfikacji maszynowej umożliwia uzyskanie większej ilości sztuk tarcicy sosnowej o lepszych właściwościach mechanicznych oraz zniwelowanie liczebności tarcicy odrzuconej.

Słowa kluczowe: tarcica konstrukcyjna, sortowanie wytrzymałościowe, metoda wizualna, metoda maszynowa, wady drewna, cechy strukturalne i geometryczne

\section{INTRODUCTION}

The demand for construction timber has been steadily increasing in recent years. To ensure structural safety of a building, construction timber must have a guaranteed strength, thus must be strength graded.

\section{WPROWADZENIE}

W ostatnich czasach sukcesywnie wzrasta zapotrzebowanie na tarcicę konstrukcyjną. Tarcica konstrukcyjna z uwagi na bezpieczeństwo budowli musi odznaczać się gwarantowaną wytrzymałością, zatem 
The strength grading according to the method used allows determining flexural modulus of the timber either indirectly (visual method) or directly (machine method). Standards and tests in strength grading of construction timber (initially by visual method only) appeared in countries with highly developed industry: USA, Canada, Finland, Sweden and the United Kingdom.

In 1977, the United Nations Economic Commission for Europe formulated an international standardsetting recommendation - ECE Recommended Standard. It was used in many European countries to develop national standards for construction timber strength grading (e.g. in Poland). Most of the standards introduced 3 grading classes for construction timber graded by visual method (in Poland, Germany, Austria, England, France and Slovakia). The Irish and Spanish standards introduced 2 grading classes, while the Portuguese -1 class, the Scandinavian -4 grading classes.

The purpose of visual grading for all standards is to ensure that each piece of timber is inspected by a wood quality controller and classified in a specific class depending on structural wood defects as well as defects in shape and processing. The use of machines, on the other hand, created the need to amend the standards concerning strength grading and to supplement them with the rules of machine-method grading. Currently, the EN 14081-1:2016-03 standard has been introduced [1]. When classifying timber with the machine method, it is assigned to strength classes according to EN 338 [2]. Two other standards are associated with this standard, which define the methods of testing the physical and mechanical wood properties and the determination of their characteristic values (EN 408 [3] and EN 384 [4]).

In different EU countries, grading with visual method produces timber classified into different grading classes (e.g. in Poland - KW, KS, KG; in Germany and Austria - S7, S10, S13; in France - STI, ST-II, ST-III; in Scandinavian countries - T3, T2, T1, T0; in Spain - ME1, ME2, and in Slovakia - S0, SI, SII), [5]. The visual method is currently used in Poland for timber strength grading. The qualifications to grade using this method are obtained through special training completed with a practical exam. After passing the examination, each participant is granted personal license to strength-grade timber according to PN-D-94021 [6] and to issue a declaration of conformity of a graded batch of timber according to the requirements of this standard [5, 7-9]. musi być sortowana wytrzymałościowo. Sortowanie wytrzymałościowe zależnie od zastosowanej metody umożliwia w sposób pośredni (metoda wizualna) albo bezpośredni (metoda maszynowa) wyznaczyć moduł sprężystości tarcicy. Normy i opracowania w obszarze wytrzymałościowego sortowania tarcicy konstrukcyjnej (na początku wyłącznie metodą wizualną) pojawiły się w krajach o wysoko rozwiniętym przemyśle: USA, Kanada, Finlandia, Szwecja i Wielka Brytania.

W 1977 roku Europejska Komisja Gospodarcza ONZ sformułowała międzynarodowe zalecenie normalizacyjne - ECE Recommended Standard. Posłużyło ono w wielu krajach europejskich do opracowania krajowych norm dotyczących sortowania wytrzymałościowego tarcicy konstrukcyjnej (m.in. w Polsce). Większa część norm wprowadziła 3 klasy sortownicze dla tarcicy konstrukcyjnej sortowanej wytrzymałościowo metodą wizualną (w Polsce, Niemczech, Austrii, Anglii, Francji i Słowacji). Normy irlandzka oraz hiszpańska wprowadziły 2 klasy sortownicze, a portugalska - 1 klasę, skandynawska -4 klasy sortownicze. Celem wizualnego sortowania dla wszystkich norm jest dokładne obejrzenie każdej sztuki tarcicy przez brakarza oraz sklasyfikowanie jej do określonej klasy, z uwagi na występujące $\mathrm{w}$ sortowanej tarcicy wady strukturalne drewna oraz wady kształtu i obróbki. Wykorzystanie natomiast maszyn wywołało konieczność nowelizacji norm, dotyczących sortowania wytrzymałościowego oraz uzupełnienia ich o zasady sortowania metodą maszynową. Obecnie wprowadzono normę EN 14081-1:2016-03 [1]. Klasyfikując metodą maszynową tarcicę, przyporządkowuje się ją do klas wytrzymałościowych według EN 338 [2]. Z tą normą są związane dwie inne normy, które określają sposoby badań właściwości fizycznych oraz mechanicznych drewna oraz wyznaczenie ich wartości charakterystycznych (EN 408 [3] i EN 384 [4]).

$\mathrm{W}$ różnych krajach UE sortując metodą wizualną uzyskuje się tarcicę sklasyfikowaną do różnych klas sortowniczych (np. w Polsce - KW, KS, KG; w Niemczech i Austrii - S7, S10, S13; we Francji - ST-I, ST-II, ST-III; w krajach skandynawskich - T3, T2, T1, T0; w Hiszpanii - ME1, ME2, na Słowacji - S0, SI, SII), [5]. W Polsce obecnie wykorzystuje się do wytrzymałościowego sortowania tarcicy metodę wizualną. Uprawnienia do sortowania tą metodą uzyskuje się poprzez specjalne szkolenie zakończone egzaminem praktycznym. Po zdaniu egzaminu każdy uczestnik otrzymuje imienne uprawnienia do wytrzymałościowego sortowania tarcicy według PN-D-94021 [6] i wystawiania deklaracji zgodności sortowanej partii tarcicy zgodnie z wymaganiami tej normy [5, 7-9]. 
The results presented in point 4 are based on the research conducted during the preparation of the doctoral dissertation by one of the article authors [10-14].

\section{STRENGTH GRADING WITH MACHINE METHOD}

Visual strength grading is a slow and timeconsuming process. Its productivity in cubic metres per hour is low. In addition, this grading is burdened by human factor errors, i.e. the grading result is determined by who is grading. Grading results can be unequal when two wood quality controllers grade the same batch of timber. The grading person in the moment of ambiguous situations subconsciously lowers the classes of timber [15]. Visual grading is flawed, so ways to grade without flaws by using special machines were initiated. These involve machines that do not destroy or damage the graded timber during the strength grading process. The aim of the machine designers was to develop devices with a simple and objective determination of wood characteristics, highly correlated with its strength properties. Wood properties with the use of machines are more correlated with wood strength properties than the properties determined during visual grading $[5,16]$.

Mechanical strength grading dates back to the sixties. The use of machines enables the combination of several simultaneously analyzed wood characteristics. The combinations of these characteristics are more correlated with the strength wood properties than each characteristic separately [5]. These machines meet standard requirements, such as full-size construction timber grading and non-destructive grading. Grading machines are based on the measurement of specific wood characteristics, which can be determined in a nondestructive method and are correlated with the wood bending. The greater the correlation between the tested characteristic and its bending strength, the more genuine the grading results of the machine are.

The use of grading machines allows obtaining objective results, and additionally modern machines grade more efficiently than human. Automatic, computer-controlled and efficient machines can be integrated into automatic process lines for the production of e.g. glued laminated timber (BSH Brettschichtholz) or solid construction timber (KVH - Konstruktionsvollholz). In these lines, the grading machines are combined with circular cross-cut saws
Wyniki przedstawione w punkcie 4 oparte sa na badaniach przeprowadzonych podczas przygotowywania rozprawy doktorskiej jednego z autorów artykułu [10-14].

\section{SORTOWANIE WYTRZYMAŁOŚCIOWE METODA MASZYNOWA}

Sortowanie wytrzymałościowe metodą wizualną jest procesem powolnym oraz czasochłonnym. Jego wydajność $w$ metrach sześciennych na godzinę jest niska. Dodatkowo to sortowanie jest obarczone ,czynnikiem ludzkim”, czyli wynik sortowania jest uwarunkowany tym, kto sortuje. Wyniki sortowania mogą być niejednakowe, gdy dwóch brakarzy przesortuje tę samą partię tarcicy. Sortujący człowiek w momencie niejednoznacznych sytuacji (tzw. sztuki graniczne) podświadomie zaniża klasy tarcicy [15]. Sortowanie metodą wizualną jest obciążone wadami, wobec tego zapoczątkowano szukanie takich sposobów sortowania, które nie byłyby obarczone tymi defektami poprzez zastosowanie specjalnych maszyn. Muszą być to maszyny, które podczas sortowania nie niszczyłyby ani nie uszkadzały sortowanej tarcicy. Celem projektantów maszyn było opracowanie urządzeń o prostym oraz obiektywnym określeniu cech drewna, wysoko skorelowanych z jego właściwościami wytrzymałościowymi. Właściwości drewna z zastosowaniem maszyn są bardziej skorelowane z wytrzymałościowymi właściwościami drewna niż właściwości wyznaczone podczas sortowania metodą wizualną $[5,16]$.

Maszynowe sortowanie wytrzymałościowe sięga lat sześćdziesiątych ubiegłego wieku. Wykorzystanie maszyn umożliwia kombinację równocześnie kilku analizowanych cech drewna. Kombinacje tych cech są bardziej skorelowane z właściwościami wytrzymałościowymi drewna niż każda cecha odrębnie [5]. Maszyny te spełniają kilka podstawowych wymagań, m.in. zapewnienie sortowania pełnowymiarowej tarcicy konstrukcyjnej oraz nieniszczący sposób sortowania. Maszyny wytrzymałościowe do sortowania tarcicy opierają się na pomiarze określonych cech drewna, które można wyznaczyć w sposób nieniszczący i są skorelowane $\mathrm{z}$ wytrzymałością drewna na zginanie. Im większa następuje korelacja pomiędzy badaną cechą a jego wytrzymałością na zginanie, tym bardziej są prawdziwe wyniki sortowania maszyny.

Wykorzystanie maszyn do sortowania pozwala na uzyskanie wyników obiektywnych, dodatkowo współczesne maszyny sortują wydajniej niż człowiek. Automatyczne, sterowane komputerowo i wydajne maszyny można wkomponować w automatyczne linie technolo- 
which, due to the grading results, cut out board fragments with unacceptable wood defects.

Due to the principle of operation of these machines, they can be classified in two groups:

1. Machines operating on the principle of flexural modulus determination, when timber is assigned to a specific strength class. Two types of these devices can be listed here:

- Bending machines, the test piece is flexibly bent. With a constant bending force and specified support spacing, the deflection is determined, and with a constant deflection value, the bending force is determined. The data and dimensions of the bending element allow determining flexural modulus at bending. This module is correlated with the wood strength. The strength in these machines is determined by the lowest flexural modulus value for the timber. This allows detecting the weakest cross-section in the graded element. Unfortunately, it is not possible to test the ends of boards with this method (about $0.5 \mathrm{~m}$ at both ends).

- Machines operating on the principle of dynamic flexural modulus impose the tested timber density determination. There are solutions in which each graded element is measured and weighed (usually on a cross conveyor) and in which it is enough to enter the average species density into the computer controlling the machine (without weighing each piece of timber). Thanks to a single blow to the front of the graded timber, it vibrates freely. Special measuring instruments analyse the vibrations as a function of time and determine the frequency of these vibrations (the first harmonic component). With the vibration frequency and timber length and density, a dynamic flexural modulus - average for the whole element - is determined. Here, the flexural modulus depends solely on the length and density of the component to be tested, so that timber of any cross-sectional dimension can be tested with these machines. With this method it is not possible to determine the position of the weakest cross-section. These machines include: Grade Master, Dynagrade, Mobile Timber Grader and Viscan. There are also ultrasound machines for timber grading. An ultrasound generating head is placed in one timber face and a receiving head in the other. The time of ultrasound transfer in wood at a known distance (length of graded timber) shall be determined. giczne do produkcji np. drewna klejonego warstwowo $\mathrm{z}$ tarcicy (BSH - Brettschichtholz) albo drewna konstrukcyjnego litego klejonego na długość (KVH - Konstruktionsvollholz). W liniach tych maszyny sortujące są zestawione z pilarkami tarczowymi poprzecznymi, które $z$ uwagi na wyniki sortowania wycinają fragmenty desek z niedopuszczalnymi wadami drewna.

$\mathrm{Z}$ uwagi na zasadę działania wymienionych maszyn można je zaliczyć do dwóch grup:

1. Maszyny działające na zasadzie wyznaczania modułu sprężystości, gdy tarcica jest przyporządkowywana do określonej klasy wytrzymałościowej. Tutaj można wyliczyć dwa rodzaje tych urządzeń:

- Maszyny działające na zasadzie zginania, badany element jest uginany sprężyście. Przy stałej sile zginającej oraz określonym rozstawie podpór wyznaczana jest strzałka ugięcia, natomiast przy stałej strzałce ugięcia określana jest siła zginająca. Dane i wymiary zginanego elementu umożliwiają wyznaczenie modułu sprężystości przy zginaniu. Moduł ten jest skorelowany z wytrzymałością drewna. Określnikiem wytrzymałości w tych maszynach jest najmniejsza wartość modułu sprężystości wyliczona dla badanej sztuki tarcicy. Pozwala to na wykrycie najsłabszego przekroju w sortowanym elemencie. Niestety nie da się tą metodą zbadać końcówek desek (po około 0,5 m z obu końców).

- Maszyny działające na zasadzie pomiaru dynamicznego modułu sprężystości wymuszają podanie gęstości badanej tarcicy. Są rozwiązania, w których każdy sortowany element jest mierzony oraz ważony (zwykle na przenośniku poprzecznym) i w których wystarczy wprowadzić do komputera sterującego maszyną średnią gęstość gatunkową (bez ważenia każdej sztuki tarcicy). Dzięki pojedynczym uderzeniom w czoło sortowanej sztuki tarcicy wprowadza się ją w drgania swobodne. Specjalne przyrządy pomiarowe analizują drgania $\mathrm{w}$ funkcji czasu i wyznaczają częstotliwość tych drgań (pierwszą harmoniczną). Mając częstotliwość drgań własnych oraz długość i gęstość tarcicy, wyznacza się dynamiczny moduł sprężystości - średni dla całego elementu. Tutaj moduł sprężystości zależy wyłącznie od długości oraz gęstości badanego elementu, dlatego maszynami tymi można badać tarcicę o dowolnych wymiarach przekroju poprzecznego. Taką metodą nie da się określić położenia najsłabszego przekroju. Do tych maszyn należą: Grade Master, Dynagrade, Mobile 
Having the time, it is possible to calculate the ultrasound speed, then at a known density of wood - dynamic flexural modulus. Triomatic applies here.

2. Machines operating on the principle of screening the graded element without coming into contact with it. Gamma or X-rays are used to screen the element to determine its characteristics (e.g. density, knottiness index) correlated with the wood strength. These include: Finnograder II and IsoGreComat [16]. Recently, the screening machines for graded timber were equipped with modules scanning the surfaces of the examined timber with optical systems using light of different wavelengths and laser light. This group includes GoldenEye 702 (see Fig. 1), [15]. GoldenEye 702 determines: density, dimensions, texture, recognizes knots, cracks, wanes, curvature, warpage of timber. In case of colour television cameras, this machine also detects decay, sapstain, pitch pockets, bark pockets and decayed knots. It is used in production plants [5]: construction timber glued laminated from sawn timber $(\mathrm{BSH})$, solid construction timber glued lengthwise for fingerjoint timber $(\mathrm{KVH})$, structural elements for the U.S. market (2"x4" system).

a)

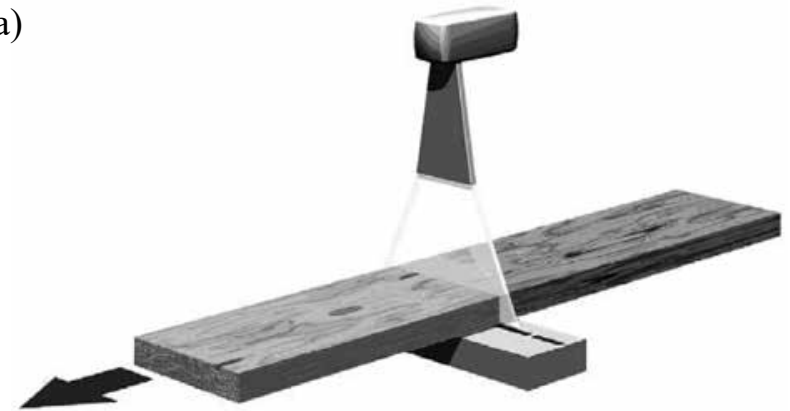

b)

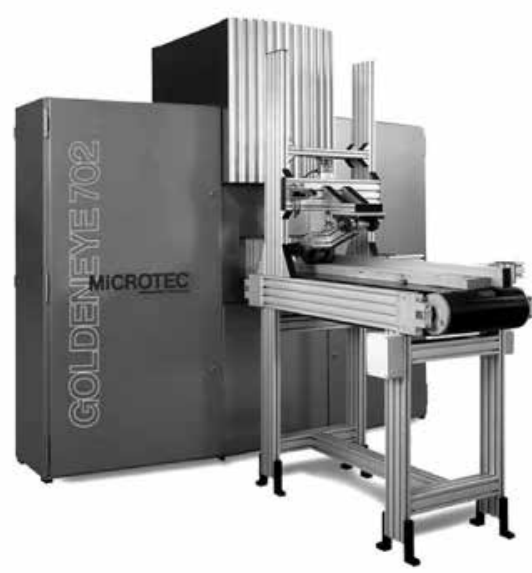

Timber Grader oraz Viscan. Stosuje się również urządzenia sortujące tarcicę przy wykorzystaniu ultradźwięków. Do jednego czoła tarcicy umieszczana jest głowica generująca ultradźwięki, a do drugiego głowica odbiorcza. Wyznacza się czas przejścia ultradźwięków w drewnie na znanym odcinku (długości sortowanej tarcicy). Mając czas, można wyliczyć prędkość ultradźwięków, potem przy znanej gęstości drewna - dynamiczny moduł sprężystości. Można tutaj zaliczyć Triomatic.

2. Maszyny działające na zasadzie podświetlania sortowanego elementu, nie stykając się z nim. Prześwietlając badany element promieniami gamma albo X, określa się cechy (np. gęstość, sękatość) skorelowane z wytrzymałością drewna. Tutaj można zaliczyć: Finnograder II oraz IsoGreComat [16]. Ostatnio maszyny prześwietlające sortowaną tarcicę zaopatrzone zostały $\mathrm{w}$ moduły skanujące powierzchnie badanej tarcicy przy zastosowaniu systemów optycznych wykorzystujących światło o różnych długościach fal i światło laserowe. Do tej grupy można zaliczyć GoldenEye 702 (rys. 1), [15]. GoldenEye 702 wyznacza gęstość, wymiary, układ włókien, rozpoznaje sęki, pęknięcia, obliny, krzywizny, zwichrowania tarcicy. W przypadku kamer telewizji kolorowej ta maszyna wykrywa także zgniliznę, siniznę, pęcherze żywiczne, zakorki, sęki zepsute. Jest ona wykorzystywana w zakładach produkcyjnych [5]: drewno konstrukcyjne klejone warstwowo z tarcicy (BSH), drewno konstrukcyjne lite klejone na długość na miniwczepy $(\mathrm{KVH})$, elementy konstrukcyjne na rynek amerykański (system 2"x4").
Fig. 1. GoldenEye 702 [15]: a - timber screening with $X$-rays, $b$ - general view of the device

Rys. 1. GoldenEye 702 [15]: a - prześwietlanie tarcicy promieniami $X, b$-widok ogólny urzadzenia 
The highest correlation coefficient with the wood strength is determined by: flexural modulus at bending and combinations of the following characteristics: flexural modulus + knottiness index, flexural modulus + density, density + knottiness index. Modern grading machines operate on the measurement of at least one of the above combinations, preferably correlated with the wood strength. The progress of science and technology changes only the applied methods and measuring devices.

Taking into account the possibility of integration into the production line, the first strength grading machines can be divided into two groups:

1. Machines which may constitute an integral part of an automated production line (should have a sufficiently high capacity, automatic timber feeding and graded timber collection (on-line operating machines).

2. Machines that make up a separate link in the production process (low productivity, manual timber feeding for grading and collection of graded timber), off-line operating machines.

In the nineties, further machines were developed which, due to their principle of operation, cannot be included in either of the two groups. These were the following EuroGreComat and Grade Master solutions. EuroGreComat had two independent principles of operation: the element was simultaneously X-rayed and bent during grading. Bending of the board made it possible to determine the flexural modulus, and X-ray - the timber density and knottiness index (see Fig. 2). The designers of this machine opted for a combination of wood properties, correlation coefficients with bending, tensile and compressive strength of wood are equal to or higher than 0.8 .

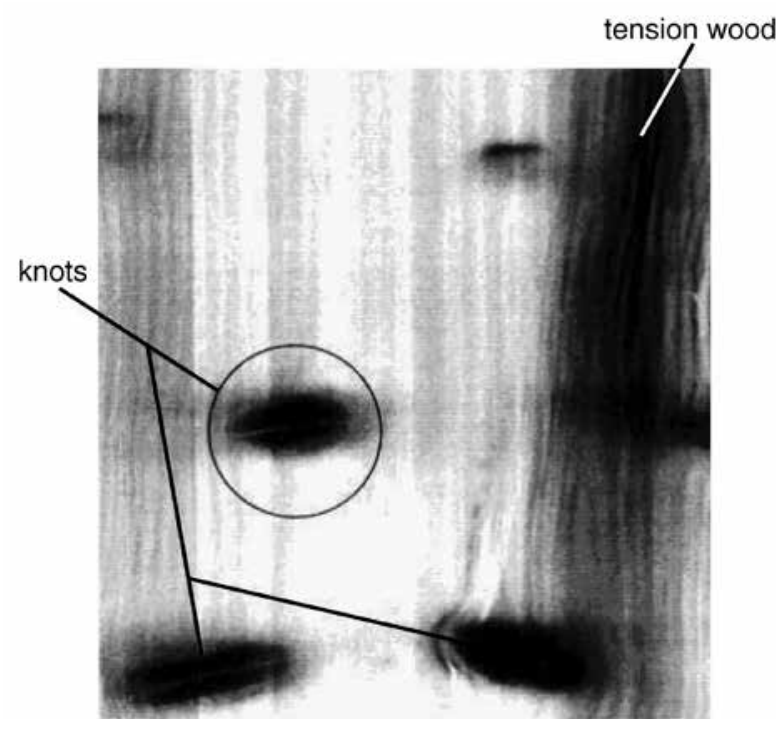

Najwyższy współczynnik korelacji z wytrzymałością drewna wyznacza moduł sprężystości przy zginaniu i kombinacje następujących cech: moduł sprężystości + sękatość, moduł sprężystości + gęstość, gęstość + sękatość. Współczesne maszyny do sortowania działają na pomiarze przynajmniej jednej z wymienionych wyżej kombinacji, najlepiej skorelowanej z wytrzymałością drewna. Postęp nauki oraz techniki zmienia wyłącznie zastosowane metody oraz urządzenia pomiarowe.

Biorąc pod uwagę możliwość włączenia do linii produkcyjnej pierwsze maszyny do sortowania wytrzymałościowego można podzielić na dwie grupy:

1. Maszyny, które mogą stanowić integralną część zautomatyzowanego ciągu produkcyjnego (powinny mieć dostatecznie wysoką wydajność, automatyczne podawanie tarcicy do sortowania oraz odbioru tarcicy przesortowanej), maszyny pracujące on-line.

2. Maszyny, które tworzą oddzielne ogniwo procesu produkcyjnego (niskiej wydajności, ręczne podawanie tarcicy do sortowania oraz odbiór tarcicy przesortowanej), maszyny off-line.

W latach 90. ubiegłego wieku powstały kolejne maszyny, których z uwagi na wykorzystaną zasadę działania nie da się włączyć do żadnej z wymienionych wcześniej dwóch grup. Stanowiły one następujące rozwiązania EuroGreComat oraz Grade Master. EuroGreComat posiadał dwie niezależne zasady działania: element podczas sortowania był jednocześnie prześwietlany promieniami $\mathrm{X}$ i uginany. Uginanie deski umożliwiało wyznaczenie modułu sprężystości, a prześwietlanie - gęstość oraz sękatość badanej tarcicy (rys. 2). Projektanci tej maszyny zdecydowali się na kombinację właściwości drewna, współczynniki korelacji z wytrzymałościami na zginanie, rozciąganie oraz ściskanie drewna są równe albo wyższe niż 0,8 .

Fig. 2. The X-ray image of the graded element using EuroGreComat [15]

Rys. 2. Postać rentgenowskiego obrazu sortowanego elementu z wykorzystaniem EuroGreComatu [15] 
Grade Master (see Fig. 3) is a device operating on the principle of dynamic flexural modulus measurement. This was done by blowing the front of a board on a cross conveyor with a suitable hammer. This impact caused the board to vibrate. The frequency of these vibrations is taken into account. The frequency of these vibrations and the density of the whole piece made it possible to determine the dynamic flexural modulus. Each board for density determination was weighed and measured. Additionally, this device was equipped with a set of four cameras, scanning the surface of the board from four sides. The camera system determined the knottiness index of the analyzed element, other defects and wood properties affecting the strength: cracks, pitch pocket, bark pockets, larval galleries and wane.

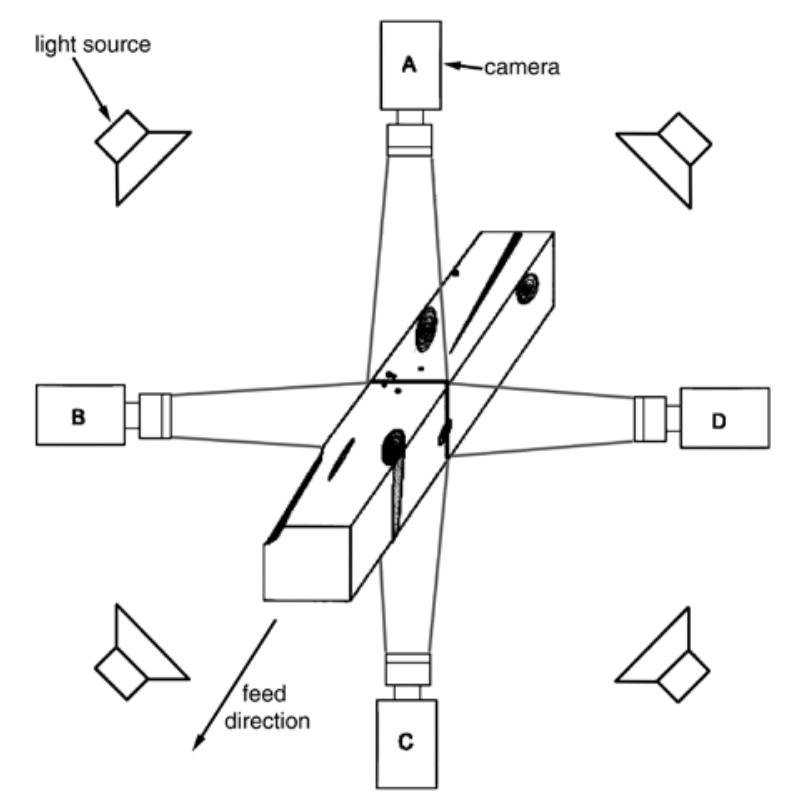

\section{VISUAL STRENGTH GRADING}

Due to the building safety, construction timber should have guaranteed strength, i.e. it should be strength graded by the wood quality controllers in sawmills. Strength grading, depending on the visual method applied (indirect method) or machine method (direct method), allows determining the flexural modulus of timber [14]. Knowing the flexural modulus and density of construction timber, it is possible to predict its strength $[5,13]$. The strength classification with visual method allows achieving higher homogeneity of timber in relation to mechanical properties than in general purpose materials [14].

The construction timber classification with visual method is specified in the PN-D-94021:2013-10
Grade Master (rys. 3) to urządzenie działające na zasadzie pomiaru dynamicznego modułu sprężystości. Zachodziło to poprzez uderzenie w czoło deski znajdującej się na przenośniku poprzecznym, odpowiednim młotkiem. To uderzenie wzbudzało $\mathrm{w}$ desce drgania. Do pomiaru jest brana częstotliwość tych drgań. Częstotliwość tych drgań i gęstość całej sztuki umożliwiała wyznaczenie dynamicznego modułu sprężystości. Każda deska do wyznaczenia gęstości była zważona oraz zmierzona. Dodatkowo to urządzenie było zaopatrzone w zestaw czterech kamer, skanując powierzchnię deski z czterech stron. System kamer określał sękatość analizowanego elementu i inne wady oraz właściwości drewna wpływające na wytrzymałość: pęknięcia, pęcherze żywiczne, zakorki, chodniki owadzie, oblinę.

Fig. 3. The principle of operation of the scanner in the Grade Master grading device [15]: A, B, C, D cameras

Rys. 3. Zasada działania skanera $w$ urzadzeniu do sortowania Grade Master [15]: A, B, C, D kamery

\section{SORTOWANIE WYTRZYMAKOŚCIOWE METODA WIZUALNA}

Z uwagi na bezpieczeństwo budynków tarcica konstrukcyjna powinna odznaczać się gwarantowaną wytrzymałością, czyli powinna być przesortowana wytrzymałościowo przez brakarzy w tartakach. Sortowanie wytrzymałościowe zależnie od wykorzystanej metody wizualnej (sposób pośredni) lub maszynowej (sposób bezpośredni) pozwala określić moduł sprężystości tarcicy [14]. Znając moduł sprężystości i gęstość tarcicy konstrukcyjnej, można przewidzieć jej wytrzymałość $[5,13]$. Stosowanie klasyfikacji wytrzymałościowej metodą wizualną umożliwia uzyskanie większej, niż w materiałach ogólnego przeznaczenia, jednorodności tarcicy w odniesieniu do właściwości mechanicznych [14]. 
standard. The scope of this standard covers edged coniferous timber, rough or planed timber, dry or green timber, thickness from $22 \mathrm{~mm}$ and minimum cross-section $2000 \mathrm{~mm}^{2}$. Conditionally, the standard may be applied to the classification of construction coniferous timber with a thickness of less than $22 \mathrm{~mm}$ but not less than $19 \mathrm{~mm}$, taking into account the minimum cross-section condition [14].

The PN-D-94021:2013-10 [6] standard applies to timber of the following wood: Scots pine (Pinus sylvestris L.), the Norway spruce (Picea abies (L.) Karst), the European silver fir (Abies alba Mill.), the European larch (Larix decidua Mill), and Douglas fir (Pseudotsuga menziesii (Mirb.) Franco). It includes not only the principles of timber classification in visual strength grading, but also specifies the moisture, dimensional, quality and marking requirements as well as test procedures for determining these characteristics $[15,17]$.

The PN-D-94021:2013-10 standard [6, 14] distinguishes:

a) strength-graded construction coniferous timber, strength-sorted - timber graded due to strength characteristics or parameters and defects in shape and processing;

b) marginal zone - one of two zones located along the entire length of each timber side with a width equal to $1 / 4$ of the plane width;

c) the worst cross-section - the conventional cross-section in the area of the maximum accumulation of knots, in particular in the marginal zones of timber, covering the projection plane of knots;

d) knottiness index - the share of knots in the worst cross-section of timber;

e) marginal area knotting index - the index covering one of the two marginal zones, i.e. one where knots occupy a larger area, the so-called worse margin;

f) general knotting index - knotting index referring to the entire timber cross-section (Fig. 4).

To define the construction timber quality class graded with visual method, the type, dimensions and degree of defect intensity that determine the timber strength characteristics, as well as the wood growth ring index and density are taken into account. Coniferous construction timber is grouped into three quality classes and the following markings are used: KW - choice class, KS - middle quality class and $\mathrm{KG}$ - lower quality class. Quality classes of particular species of coniferous construction timber have been qualified to strength classes included in PN-EN 1995 -
Klasyfikacja tarcicy konstrukcyjnej metodą wizualną określonajest w normiePN-D-94021:2013-10[6].Zakresem tej normy objęta jest tarcica iglasta obrzynana, szorstka lub strugana, sucha albo mokra, grubości od $22 \mathrm{~mm}$ i minimalnym przekroju poprzecznym $2000 \mathrm{~mm}^{2}$. Warunkowo normę można zastosować do klasyfikacji tarcicy konstrukcyjnej iglastej o grubości poniżej $22 \mathrm{~mm}$, ale nie mniejszej niż $19 \mathrm{~mm}$, uwzględniając warunek minimalnego przekroju poprzecznego [14].

Norma PN-D-94021:2013-10 [6] dotyczy tarcicy z sosny zwyczajnej (Pinus sylvestris L.), świerka pospolitego (Picea abies (L.) Karst), jodły pospolitej (Abies alba Mill.), modrzewia europejskiego (Larix decidua Mill), daglezji zielonej (jedlicy zielonej) (Pseudotsuga menziesii (Mirb.) Franco). Obejmuje ona nie tylko zasady klasyfikacji tarcicy przy sortowaniu wytrzymałościowym metodą wizualną, ale także podaje wymagania wilgotnościowe, wymiarowe, jakościowe, oznakowania i procedury badawcze wyznaczenia tych cech $[15,17]$.

Norma PN-D-94021:2013-10 [6, 14] wyodrębnia:

a) tarcicę konstrukcyjną iglastą sortowaną wytrzymałościowo - tarcica sortowana $\mathrm{z}$ uwagi na cechy lub parametry wytrzymałościowe oraz wady kształtu i obróbki;

b) strefę marginalną - jedną z dwóch stref, znajdującą się na całej długości każdego z boków tarcicy, o szerokości równej 1/4 szerokości płaszczyzny;

c) przekrój poprzeczny najgorszy - przekrój umowny, występujący $\mathrm{w}$ obszarze maksymalnego nagromadzenia sęków, w szczególności w strefach marginalnych, obejmujący płaszczyznę rzutowania sęków;

d) wskaźnik sękatości - udział sęków na powierzchni najgorszego przekroju poprzecznego tarcicy;

e) wskaźnik sękatości strefy marginalnej (USM) wskaźnik obejmujący jedną z dwóch stref marginalnych, czyli taką, gdzie sęki zajmują większą powierzchnię, tzw. gorszy margines;

f) ogólny wskaźnik sękatości (USC) - wskaźnik sękatości odnoszący się do całego przekroju poprzecznego tarcicy (rys. 4).

Do zdefiniowania klasy jakości tarcicy konstrukcyjnej sortowanej metodą wizualną uwzględnia się rodzaj, wymiary i stopień nasilenia wad, które decydują o cechach wytrzymałościowych tarcicy, jak również słoistość i gęstość drewna. Iglastą tarcicę konstrukcyjną grupuje się na trzy klasy jakości oraz stosuje się poniższe oznaczenia: KW - klasa wyborowa, KS - klasa średniej jakości, KG - klasa gorszej jakości. Klasy jakości poszczególnych gatunków tarcicy konstrukcyjnej iglastej zostały zakwalifikowane do klas wytrzymałościowych, zawartych w PN-EN 1995-1-1:2010 


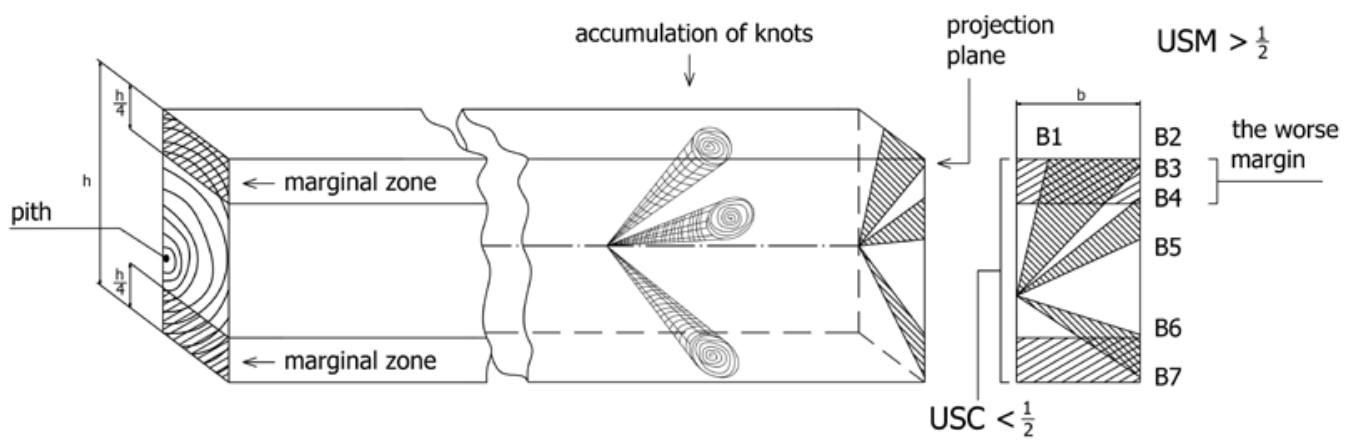

Fig. 4. Ways of projecting knots (USM - marginal area knotting index; USC-general knotting index; B1, B2, B3, B4, B5, B6, B7 - points determining the diameter of knots on the side and on the plane) [14, 15]

Rys. 4. Sposoby rzutowania sęków (USM - wskaźnik sękatości strefy marginalnej; USC-ogólny wskaźnik sękatości; B1, B2, B3, B4, B5, B6, B7 - punkty wyznaczające średnicę sęków na boku i na płaszczyźnie) [14, 15]

1-1:2010 [18], National Annex PN-EN 1995-1-1:2010

[19]. Construction timber quality graded with visual method is determined by visual inspection in the area with the highest intensity of defects according to PND-94021:2013-10 [6]. Dimensions of permissible defects are determined in accordance with PN-EN 1310:2000 [20] and PN-EN 1311:2000 [21] standards. During the grading process, the weakest cross-section with the largest accumulation of defects, e.g. knots, should be found in the timber. The strength of the weakest cross-section determines the strength of the entire timber. When testing the weakest cross-section, the entire timber length is determined, granting a class or rejecting it. During visual grading it is also necessary to determine the defects and structural features of wood, such as: knots, cracks, growth ring index, slope of grain, presence of decay and insect damage, defects in processing and shape: wanes, distortion [5, 11-15, 22-23]. In case a reaction wood (compression wood) is present, a cross-section is found in which there is an enlargement of the summer wood zone in the annual rings (see Fig. 5). The width of the reaction wood zone determined in one plane and on one side refers to the circumference of the cross-section of timber [14, 15].

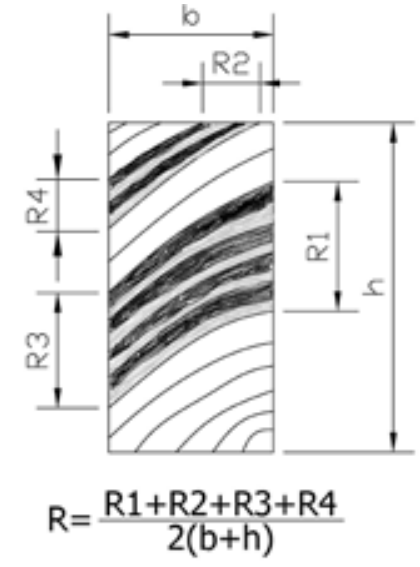

[18], Załącznik krajowy PN-EN 1995-1-1:2010 [19]. Tarcicę konstrukcyjną sortowaną metodą wizualną pod względem jakościowym określa się dokonując oględzin w obszarze największego nasilenia wad według PN-D-94021:2013-10 [6]. Wymiary dopuszczalnych wad wyznacza się zgodnie z PN-EN 1310:2000 [20] i PN-EN 1311:2000 [21]. Podczas sortowania należy w ocenianej sztuce tarcicy odnaleźć najsłabszy przekrój, w którym znajduje się największe skupienie wad, np. sęków. Wytrzymałość najsłabszego przekroju rozstrzyga o wytrzymałości całej sztuki tarcicy. Badając najsłabszy przekrój, określa się tarcicę na całej długości, przydzielając jej odpowiednią klasę lub uznając ją jako odrzut. Podczas sortowania wizualnego należy również określić wady i cechy strukturalne drewna, jak: sęki, pęknięcia, słoistość, skręt włókien, obecność zgnilizny i chodników owadzich, wady obróbki i kształtu: obliny, krzywizny [5, 11-15, 22-23]. W przypadku obecności drewna reakcyjnego (twardzicy), wyszukuje się przekrój poprzeczny, w którym występuje poszerzenie strefy drewna późnego w słojach rocznych (rys. 5). Szerokość strefy drewna reakcyjnego wyznaczonej na jednej płaszczyźnie i na jednym boku odnosi się do obwodu przekroju poprzecznego tarcicy $[14,15]$.
Fig. 5. Measurement of the reactive wood share according to $P N-D-94021: 2013-10$ [6, 14, 15]

Rys. 5. Pomiar udziału drewna reakcyjnego wg PN-D94021:2013-10 [6, 14, 15] 
Permissible defects of construction timber graded with visual method depending on its quality class are summarised in Table 1.
Dopuszczalne wady tarcicy konstrukcyjnej sortowanej metodą wizualną w zależności od jej klasy jakości zestawiono w tabeli 1.

Table 1. Permissible defects of construction timber graded with visual method according to PN-D-94021:2013-10 [6, 14-15]

Tabela 1. Dopuszczalne wady tarcicy konstrukcyjnej sortowanej metoda wizualna wedtug PN-D-94021:2013-10 [6, 14-15]

\begin{tabular}{|c|c|c|c|c|c|c|}
\hline \multirow{3}{*}{\multicolumn{2}{|c|}{$\begin{array}{c}\text { THE CLASSIFICATION BASIS } \\
\text { KNOTS, REGARDLESS OF QUALITY, EXPRESSED AS } \\
\text { A KNOTTING INDEX USM* }\end{array}$}} & KW & \multicolumn{2}{|c|}{ KS } & \multicolumn{2}{|c|}{ KG } \\
\hline & & \multirow[b]{2}{*}{$\leq 1 / 4$} & Variant 1 & Variant 2 & Variant 1 & Variant 2 \\
\hline & & & $\leq 1 / 2$ & $\leq 1 / 2$ & $>1 / 2$ & \\
\hline \multicolumn{2}{|c|}{$\begin{array}{l}\text { OVER THE ENTIRE CROSS-SECTION OF TIMBER } \\
\text { USC }\end{array}$} & $\begin{array}{l}4 \leq 1 / 4 \\
4 \leq 1 / 4 \\
4 \leq 1 / 3\end{array}$ & $\leq 1 / 4$ & $\leq 1 / 2$ & $\leq 1 / 3$ & \\
\hline \multicolumn{2}{|r|}{$\begin{array}{c}\text { SLOPE OF GRAIN } \\
\text { (diagonal grain path) }\end{array}$} & $\begin{array}{l}\leq 7 \% \\
(1: 14)\end{array}$ & \multicolumn{2}{|c|}{$\begin{array}{l}\leq 10 \% \\
(1: 10)\end{array}$} & \multicolumn{2}{|c|}{$\begin{array}{l}\leq 16 \% \\
(1: 6)\end{array}$} \\
\hline \multirow{3}{*}{$\begin{array}{l}\text { CRACKS, RESIN } \\
\text { POCKETS, BARK } \\
\text { POCKETS } \\
\text { AND CATFACES: }\end{array}$} & \multirow{2}{*}{$\begin{array}{l}\text { deep, not crossing to the face, sides and } \\
\text { opposite plane (not including defects less } \\
\text { than } 300 \mathrm{~mm} \text { in length) }\end{array}$} & $\begin{array}{l}\text { permissible, length up to } 1 / 4 \text { of the piece } \\
\text { length and not longer than } 600 \mathrm{~mm}\end{array}$ & \multicolumn{2}{|c|}{$\begin{array}{l}\text { permissible, length up to } 1 / 4 \\
\text { of the piece length and not } \\
\text { longer than } 600 \mathrm{~mm}\end{array}$} & \multicolumn{2}{|c|}{$\begin{array}{l}\text { permissible, length up to } 1 / 4 \\
\text { of the piece length and not } \\
\text { longer than } 900 \mathrm{~mm}\end{array}$} \\
\hline & & depth up to $1 / 3$ of the piece thickness & \multicolumn{2}{|c|}{$\begin{array}{l}\text { depth up to } \\
1 / 2 \text { of the piece thickness }\end{array}$} & \multicolumn{2}{|c|}{$\begin{array}{l}\text { depth up to } 2 / 3 \text { of the piece } \\
\text { thickness }\end{array}$} \\
\hline & frontal non-crossing, crossing and circular & permissible, length up to $1 / 1$ piece width & \multicolumn{2}{|c|}{$\begin{array}{l}\text { permissible, length up to } \\
1 / 1 \text { piece width }\end{array}$} & \multicolumn{2}{|c|}{$\begin{array}{c}\text { permissible, length up } \\
\text { to } 1 \frac{1}{2} \\
\text { piece width }\end{array}$} \\
\hline & DECAY & impermissible & \multicolumn{2}{|c|}{ impermissible } & \multicolumn{2}{|c|}{ impermissible } \\
\hline & INSECT DAMAGE & impermissible & \multicolumn{2}{|c|}{ impermissible } & \multicolumn{2}{|c|}{ impermissible } \\
\hline & SAPSTAIN & permissible & \multicolumn{2}{|c|}{ permissible } & \multicolumn{2}{|c|}{ permissible } \\
\hline \multicolumn{2}{|c|}{ REACTION WOOD (COMPRESSION WOOD) } & $\begin{array}{c}\text { permissible } \\
\text { up to } 1 / 5 \text { of the girth }\end{array}$ & \multicolumn{2}{|c|}{$\begin{array}{c}\text { permissible } \\
\text { up to } 1 / 5 \text { of the girth }\end{array}$} & \multicolumn{2}{|c|}{$\begin{array}{c}\text { permissible } \\
\text { up to } 1 / 5 \text { of the girth }\end{array}$} \\
\hline \multicolumn{2}{|r|}{ GROWTH RING INDEX } & $\leq 4 \mathrm{~mm}$ & \multicolumn{2}{|c|}{$\leq 6 \mathrm{~mm}$} & \multicolumn{2}{|c|}{$\leq 10 \mathrm{~mm}$} \\
\hline \multicolumn{2}{|c|}{ Minimum DENSITY of timber** at a moisture content of $20 \%$} & $\geq 450 \mathrm{~kg} / \mathrm{m}^{3}$ & \multicolumn{2}{|c|}{$\geq 420 \mathrm{~kg} / \mathrm{m}^{3}$} & \multicolumn{2}{|c|}{$\geq 400 \mathrm{~kg} / \mathrm{m}^{3}$} \\
\hline \multicolumn{2}{|c|}{$\begin{array}{l}\text { WANE is permitted along the entire length of two edges of one } \\
\text { plane or one side, occupying a total of }\end{array}$} & $\begin{array}{l}\text { up to } 1 / 4 \text { thickness and } 1 / 4 \text { width of timber } \\
\text { piece }\end{array}$ & \multicolumn{2}{|c|}{$\begin{array}{l}\text { up to } 1 / 4 \text { thickness and } 1 / 4 \\
\text { width of timber piece }\end{array}$} & \multicolumn{2}{|c|}{$\begin{array}{l}\text { - at a distance of up to } 300 \\
\text { mm from faces } u[\text { to } 1 / 3 \text { of } \\
\text { the thickness and } 1 / 3 \text { of the } \\
\text { piece width } \\
\text { - at a distance of more than } \\
300 \text { mm from faces up to } \\
1 / 3 \text { of the thickness and } 1 / 3 \\
\text { of the piece width }\end{array}$} \\
\hline \multicolumn{2}{|c|}{ BOW - LONGITUDINAL CURVATURE OF PLANES } & $\leq 10 \mathrm{~mm}$ & & $\mathrm{~mm}$ & & $\mathrm{~nm}$ \\
\hline SPRING - L & IGITUDINAL CURVATURE OF THE SIDES & $\leq 8 \mathrm{~mm}$ & & & & \\
\hline & ST IN RELATION UP TO WIDTH & $\leq 1 \mathrm{~mm} / 25 \mathrm{~mm}$ & $\leq 1 \mathrm{~m}$ & $25 \mathrm{~mm}$ & $\leq 2 \mathrm{mr}$ & $25 \mathrm{~mm}$ \\
\hline & CROSS CURVATURE TO WIDTH & $\leq 1 \mathrm{~mm} / 25 \mathrm{~mm}$ & $\leq 1 \mathrm{~m}$ & $25 \mathrm{~mm}$ & $\leq 2 \mathrm{mr}$ & $25 \mathrm{~mm}$ \\
\hline & CRACKS, KERF WAVINESS & permissible within the thickness & Ind width dev & ions specified & r basic dimer & \\
\hline & LELISM OF PLANES AND SIDES & $\begin{array}{l}\text { planes should be parallel to each other, } \\
\text { deviations from parallelism should be wit } \\
\text { specifie }\end{array}$ & $\begin{array}{l}\text { sides of edge } \\
\text { hin the limits } \\
\text { for the basic }\end{array}$ & $\begin{array}{l}\text { mber should b } \\
\text { acceptable thi } \\
\text { mensions }\end{array}$ & $\begin{array}{l}\text { perpendicula } \\
\text { kness and wic }\end{array}$ & $\begin{array}{l}\text { o planes; } \\
\text { deviations }\end{array}$ \\
\hline & PERPENDICULARITY OF FACES & $\begin{array}{r}\text { faces should be perpendicular to planes a } \\
\text { the permissil }\end{array}$ & $\begin{array}{l}\text { id sides; devic } \\
\text { le deviations }\end{array}$ & $\begin{array}{l}\text { ons from perpe } \\
\text { timber length }\end{array}$ & idicularity sho & d be within \\
\hline
\end{tabular}

* For die squares and balks, the margins specified for each of the four longitudinal timber surface areas are taken into account.

** When the growth ring index criterion is met, the density is not taken into account. 


\section{THE RESULTS OF THE CONSTRUCTION TIMBER CLASSIFICATION TESTS}

Structural Scots pine sawn timber with from $10 \%$ to $15 \%$ moisture content from these four natural forest regions of Poland was used in the tests:

- Mazowiecko-Podlaska Natural Forest Region, raw material from the Garwolin Forest Inspectorate;

- Małopolska Natural Forest Region, raw material from the Przedbórz Forest Inspectorate;

- Śląska Natural Forest Region, raw material from the Kędzierzyn-Koźle Forest Inspectorate, and

- Carpathian Natural Forest Region, raw material from the Piwniczna Forest Inspectorate.

\subsection{Visual classification}

Visual strength grading was performed in accordance with PN-D-94021:2013-10 [6].

During the classification, the pine timber thickness, width and length were measured. During the visual inspection of each timber piece, all structural and geometric features of the timber, such as the thickness, width and length of the timber, were measured: knots, slope of grain, cracks, resin pockets, bark pockets and bark scorches, decay, insect damage, sapstain, compression wood, growth ring index (rate f growth), density, wane, bow, spring, twist, cup, scratches, kerf waviness, unevenness of planes and sides and non-parallelism of faces. Knots, usually their size and position on the cross-section of the graded timber, were the decisive factor determining the timber quality class. The weakest cross-section, with the largest knot or the largest accumulation of knots, was found along the entire timber piece length. After determining the weakest cross-section, the ratio of knot (knots) area to the area of the entire crosssection, including the knot area in the marginal zone to the area of this zone, was determined. The "worse" margin was selected during the classification, i.e. the one on the cross-section where knots occupy a larger area. Auxiliary sheets of paper with the dimensions of the cross-section of the graded piece, on which the knots $[5,13]$ were projected, were used to determine the growth ring index coefficients.

As a result of the grading timber from Mazowiecko - Podlaska Natural Forest Region, the largest number of timber pieces was obtained in the KW class (6 pieces) and in the KS class (13 pieces) in relation to the results of timber grading from other regions. The reject accounted for $41.7 \%$ of the total timber from this region. For the timber obtained from the Małopolska Natural Forest Region, 4

\section{WYNIKI BADAŃ KLASYFIKACJI TARCICY KONSTRUKCYJNE}

Do badań zastosowano sosnową tarcicę konstrukcyjną o wilgotności od $10 \%$ do $15 \%$, pochodzącą z czterech krain przyrodniczo-leśnych Polski:

- Mazowiecko-Podlaska Kraina Przyrodniczo-Leśna, surowiec z Nadleśnictwa Garwolin,

- Małopolska Kraina Przyrodniczo-Leśna, surowiec z Nadleśnictwa Przedbórz,

- Śląska Kraina Przyrodniczo-Leśna, surowiec z Nadleśnictwa Kędzierzyn-Koźle,

- Karpacka Kraina Przyrodniczo-Leśna, surowiec z Nadleśnictwa Piwniczna.

\subsection{Klasyfikacja wizualna}

Wytrzymałościowe sortowanie metodą wizualną wykonano zgodnie z normą PN-D-94021:2013-10 [6].

Podczas klasyfikacji dokonano pomiaru grubości, szerokości i długości tarcicy sosnowej. W trakcie oględzin każdej sztuki tarcicy wykonano pomiar wszystkich występujących w danej sztuce tarcicy cech strukturalnych i geometrycznych, takich jak: sęki, skręt włókien, pęknięcia, pęcherze żywiczne, zakorki i zabitki, zgnilizna, chodniki owadzie, sinizna, twardzica, słoistość, gęstość, oblina, krzywizny podłużne płaszczyzn i boków, wichrowatość w odniesieniu do szerokości, krzywizny poprzeczne w odniesieniu do szerokości, rysy, falistość rzazu, nierównoległość płaszczyzn i boków, nieprostopadłość czół. Zwykle decydującym wskaźnikiem o klasie jakości tarcicy stanowiły sęki, zazwyczaj ich wielkość oraz położenie na przekroju poprzecznym sortowanej sztuki tarcicy. Na całej długości sztuki tarcicy wyszukano najsłabszy przekrój, w którym znajduje się największy sęk lub największe skupisko sęków. Po określeniu najsłabszego przekroju określono stosunek powierzchni sęka (sęków) do powierzchni całego przekroju poprzecznego, także powierzchnię sęka w strefie marginalnej do powierzchni tej strefy. W czasie klasyfikacji selekcjonowano margines „gorszy”, czyli ten na przekroju poprzecznym, którego sęki zajmują większą powierzchnię. Do ustalenia współczynników sękatości zastosowano pomocnicze kartki papieru o wymiarach przekroju poprzecznego sortowanej sztuki, na której rzutowano znajdujące się w niej sęki $[5,13]$.

W wyniku sortowania tarcicy z Mazowiecko-Podlaskiej Krainy Przyrodniczo-Leśnej uzyskano najwięcej sztuk tarcicy w klasie KW (6 sztuk) oraz w klasie KS (13 sztuk) w odniesieniu do wyników sortowania tarcicy pochodzącej z pozostałych krain. Odrzut stanowił $41,7 \%$ całości tarcicy z tej krainy. Dla tarcicy pozy- 
pieces were graded in the KW class and 10 pieces in the KS class. The most numerous group was rejected timber -29 pieces, which was higher by 7 pieces than the KG class. Śląska Natural Forest Region was distinguished by 3 timber pieces in the KW class and 8 pieces in the KS class. 28 rejected timber pieces were obtained in this region were obtained, which constituted $43.1 \%$ in relation to the whole timber batch from this region. 26 timber pieces were assigned to the KG class. Timber obtained from the Carpathian Natural Forest Region was clearly the worst of the entire tested batch. Only 1 timber piece in the KW class and 3 timber pieces in the KS class were graded. The highest number of rejected pieces was graded, as many as 29 pieces, which accounted for $58 \%$ of the total number of timber from this region. Mainly by knots (15 pieces) determined the rejection. In the remaining cases, wanes (5 pieces), cracks (2 pieces), slope of grain (1 piece), and other defects (2 pieces) [12, 13].

On the basis of the tests, the obtained results of visual classification were compared with the percentage of particular quality classes of coniferous timber, taking into account its origin (Table 2).

\begin{tabular}{|c|c|c|c|c|}
\hline REGION & KW & KS & KG & rejected \\
\hline $\begin{array}{c}\text { Mazowiecko-Podlaska } \\
\text { Natural Forest Region }\end{array}$ & $10 \%$ & $21.67 \%$ & $26.67 \%$ & $41.67 \%$ \\
\hline $\begin{array}{c}\text { Małopolska } \\
\text { Natural Forest Region }\end{array}$ & $6.15 \%$ & $15.38 \%$ & $33.85 \%$ & $44.60 \%$ \\
\hline $\begin{array}{c}\text { Śląska } \\
\text { Natural Forest Region }\end{array}$ & $4.62 \%$ & $12.31 \%$ & $40.00 \%$ & $43.08 \%$ \\
\hline $\begin{array}{c}\text { Karpacka } \\
\text { Natural Forest Region }\end{array}$ & $2.00 \%$ & $6.00 \%$ & $34.00 \%$ & $58.00 \%$ \\
\hline TOTAL & $5.83 \%$ & $14.17 \%$ & $33.75 \%$ & $46.25 \%$ \\
\hline
\end{tabular}

The table shows that $46.25 \%$ of the tested pine timber was rejected, $33.75 \%$ of the timber was classified as the KG class, $14.17 \%$ of the timber was graded in the KS class, while only $5.83 \%$ of the timber was qualified to the best KW class. According to PN-EN 1995-1-1:2010 [18] and the National Annex to PN-EN 1995-1-1:2010 [19], the KS quality class corresponds to strength class $\mathrm{C} 24$, whereas the $\mathrm{KG}$ class to $\mathrm{C} 20$.

\subsection{Machine classification}

The test was performed under industrial conditions using WoodEye Cross Cut. 10 pieces of pine timber $(37 \times 48 \mathrm{~mm}$ cross section) were selected from skanej z Małopolskiej Krainy Przyrodniczo-Leśnej wysortowano w klasie sortowniczej KW - 4 sztuki, a w klasie KS - 10 sztuk. Najliczniejszą grupę stanowiła tarcica przyporządkowana jako odrzut - 29 sztuk, która była większa o 7 sztuk od klasy KG. Śląska Kraina Przyrodniczo-Leśna odznaczała się 3 sztukami tarcicy w klasie KW i 8 sztukami w klasie KS. Uzyskano w tej krainie 28 sztuk tarcicy należącej do odrzutu, co stanowiło $43,1 \% \mathrm{w}$ stosunku do całej partii tarcicy z tej krainy. Do klasy KG przyporządkowano 26 sztuk tarcicy. Tarcia pozyskana z Karpackiej Krainy Przyrodniczo-Leśnej była wyraźnie najgorsza z całej badanej partii. Wysortowano tylko 1 sztukę tarcicy w klasie KW i 3 sztuki tarcicy w klasie KS. Wysortowano największą liczbę sztuk, aż 29 jako odrzut, co stanowiło $58 \%$ całości tarcicy $\mathrm{z}$ tej krainy. O odrzuceniu tych sztuk przede wszystkim zadecydowały sęki (15 sztuk). W pozostałych przypadkach obliny (5 sztuk), pęknięcia (2 sztuki), skręt włókien (1 sztuka) i inne wady (2 sztuki) $[12,13]$.

Na podstawie badań zestawiono uzyskane wyniki klasyfikacji wizualnej $\mathrm{z}$ udziałem procentowym poszczególnych klas jakości iglastej tarcicy z uwzględnieniem jej pochodzenia (tabela 2).

Table 2. Results of classes obtained as a result of visual strength grading tests according to PN-D-94021:2013-10 [5, 6, 12, 13]

Tabela 2. Wyniki uzyskanych klas w efekcie badań sortowania wytrzymatościowego metoda wizualna wedlug $P N$ D-94021:2013-10 [5, 6, 12, 13]

Z tabeli wynika, że $46,25 \%$ badanej tarcicy sosnowej stanowił odrzut, 33,75\% tarcicy określono jako klasę KG, 14,17\% tarcicy wysortowano w klasie $\mathrm{KS}$, natomiast tylko 5,83\% tarcicy zakwalifikowano do najlepszej klasy KW. Zgodnie z PN-EN 1995-11:2010 [18] i Załącznikiem krajowym PN-EN 19951-1:2010 [19] klasa jakości KS odpowiada klasie wytrzymałościowej C24, natomiast klasa KG - C20.

\subsection{Klasyfikacja maszynowa}

Badanie zostało wykonane w warunkach przemysłowych przy użyciu urządzenia WoodEye Cross Cut. Z każdej krainy przyrodniczo-leśnej Polski wybrano 
each natural forest region of Poland. The length of the tested elements was $4.05 \mathrm{~m}$. Each timber piece reached the WoodEye machine, then, after classification, it was transferred via a feed conveyor to a box appropriate for a given class. WoodEye is an automatic visual wood control system. It determines the quality of boards and the inspection is carried out visually to identify defects: knots, cracks, size or position flaws.

The results of the visual and WoodEye Cross Cut strength grading of timber batches are shown in Table 3. po 10 sztuk tarcicy sosnowej o wymiarze przekroju poprzecznego $37 \times 48 \mathrm{~mm}$. Długość badanych elementów wynosiła $4,05 \mathrm{~m}$. Każda sztuka tarcicy docierała do urządzenia WoodEye, następnie po klasyfikacji przenośnikiem podawczym trafiała do boksu odpowiedniego dla danej klasy.

WoodEye jest automatycznym wizualnie systemem kontrolującym drewno. Określa jakość desek, a kontrolę przeprowadza się wizualnie, żeby określić defekty: sęki, pęknięcia, błędy wielkości czy pozycji.

Wyniki badań sortowania wytrzymałościowego partii tarcicy metodą wizualną i przy użyciu urządzenia WoodEye Cross Cut przedstawiono w tabeli 3.

Table 3. Comparison of grading classes during visual classification and with WoodEye Cross Cut of timber originating from different natural forest regions of Poland

Tabela 3. Porównanie klas sortowniczych podczas klasyfikacji wizualnej i przy użyciu urządzenia WoodEye Cross Cut, pochodzacej z poszczególnych krain przyrodniczo-leśnych Polski

\begin{tabular}{|c|c|c|c|c|c|c|c|c|}
\hline No & $\begin{array}{c}\text { Visual } \\
\text { grading KW, } \\
\text { pcs. }\end{array}$ & $\begin{array}{c}\text { WoodEye } \\
\text { grading, } \\
\text { pcs. }\end{array}$ & $\begin{array}{c}\text { Visual } \\
\text { grading KS, } \\
\text { pcs. }\end{array}$ & $\begin{array}{c}\text { WoodEye } \\
\text { grading, } \\
\text { pcs. }\end{array}$ & $\begin{array}{c}\text { Visual } \\
\text { grading KG, } \\
\text { pcs. }\end{array}$ & $\begin{array}{c}\text { WoodEye } \\
\text { grading, } \\
\text { pcs. }\end{array}$ & $\begin{array}{c}\text { Visual } \\
\text { grading } \\
\text { rejection, } \\
\text { pcs. }\end{array}$ & $\begin{array}{c}\text { WoodEye } \\
\text { grading } \\
\text { rejection, } \\
\text { pcs. }\end{array}$ \\
\hline A & 1 & 2 & 2 & 4 & 3 & 4 & 4 & 0 \\
\hline B & 1 & 2 & 1 & 3 & 3 & 4 & 5 & 1 \\
\hline C & 1 & 2 & 1 & 2 & 2 & 4 & 6 & 2 \\
\hline D & 0 & 1 & 1 & 2 & 1 & 3 & 8 & 4 \\
\hline
\end{tabular}

Grading timber with WoodEye Cross Cut results in a significant increase in the number of pieces in the higher classes in relation to the visual grading results and a decrease in the number of pieces in the lowest grades. Visual grading resulted in only 3 pieces of the KW-class timber (8\%) and 7 pieces $(18 \%)$ with WoodEye Cross Cut. Rejected timber in visual grading constituted 58\%, while with WoodEye Cross Cut $-18 \%$.

\section{SUMMARY}

The changes taking place on the market of building materials caused a growing demand for construction timber with guaranteed strength. The presented analysis presented the most important issues related to the verification of structural and geometric characteristics during strength grading of construction timber by visual and machine method. In conclusion, the basic guidelines, which can be used for the classification of construction timber in sawmills, were specified [14]. On the
Sortując tarcicę przy użyciu urządzenia WoodEye Cross Cut, uzyskuje się znaczny wzrost liczby sztuk przyporządkowanych do wyższych klas w odniesieniu do wyników sortowania metodą wizualną, a spadek ilości sztuk tarcicy najniższej klasy. W wyniku sortowania wizualnego uzyskano tylko 3 sztuki tarcicy klasy KW (8\%), a przy zastosowaniu urządzenia WoodEye Cross Cut - aż 7 sztuk (18\%). Tarcica przeznaczona na odrzut przy sortowaniu wizualnym stanowiła $58 \%$, zaś przy sortowaniu z wykorzystaniem urządzenia WoodEye Cross Cut - 18\%.

\section{PODSUMOWANIE}

Zmiany zachodzące na rynku materiałów budowlanych spowodowały rosnące zapotrzebowanie na tarcicę konstrukcyjną o wytrzymałości gwarantowanej. Ukazana analiza przedłożyła najistotniejsze zagadnienia związane $\mathrm{z}$ weryfikacją cech strukturalnych i geometrycznych w trakcie sortowania wytrzymałościowego tarcicy konstrukcyjnej metodą wizualną i maszynową. W wyniku przeanalizowanych rozważań sprecyzowano bazowe wytyczne, które mogą posłużyć przy klasyfikacji tarcicy konstrukcyjnej iglastej 
basis of the conducted test it was found that during visual structural pine timber classification there is a significant amount of rejections, as much as $46.25 \%$ in the whole batch. It is worth noting that similar results of strength grading of Scots pine structural timber form Poland were obtained in publications $[5,24]$ and Scots pine structural timber form German obtained in publication [25]. Grading with WoodEye Cross Cut allows for a significant increase in the number of pieces of timber in higher classes with better mechanical properties and a decrease in the number of the lowest classes, which is a sufficient financial benefit for the owners of sawmills applying this classification [10]. w tartakach [14]. Na podstawie przeprowadzonych badań stwierdzono, że podczas klasyfikacji wizualnej sosnowej tarcicy konstrukcyjnej występuje znaczna ilość odrzutów, aż 46,25\% w całej partii. Warto zauważyć, że zbliżone wyniki sortowania wytrzymałościowego sosnowej tarcicy konstrukcyjnej z Polski uzyskano w publikacjach $[5,24]$, a sosnowej tarcicy konstrukcyjnej z Niemiec w publikacji [25]. Sortowanie na podstawie urządzenia WoodEye Cross Cut umożliwia uzyskanie znacznego przyrostu liczebności sztuk tarcicy w wyższych klasach o lepszych właściwościach mechanicznych oraz spadek liczebności klas najniższych, co stanowi dostateczną korzyść finansową dla właścicieli tartaków stosujących omówioną klasyfikację [10].

\section{REFERENCES}

[1] PN-EN 14081-1:2016-03 Konstrukcje drewniane - Drewno konstrukcyjne sortowane wytrzymałościowo o przekroju prostokątnym - Część 1: Wymagania ogólne (Timber structures - Strength-graded construction timber with rectangular cross section - Part 1: General requirements).

[2] PN-EN 338:2016-06 Drewno konstrukcyjne - Klasy wytrzymałości (Construction timber - Strength classes).

[3] PN-EN 408+A1:2012 Konstrukcje drewniane - Drewno konstrukcyjne lite i klejone warstwowo - Oznaczanie niektórych właściwości fizycznych i mechanicznych (Wooden structures - Structural solid and glulam wood Designation of certain physical and mechanical properties).

[4] PN-EN 384:2016-10 Drewno konstrukcyjne-Oznaczanie wartości charakterystycznych właściwości mechanicznych i gęstości (Construction timber - Determination of characteristic mechanical properties and density).

[5] Krzosek S.: Wytrzymatościowe sortowanie polskiej sosnowej tarcicy konstrukcyjnej różnymi metodami (Strengthsorting of the Polish pine structural sawn wood using various methods), Wydawnictwo SGGW, Warszawa 2009.

[6] PN-D-94021:2013-10 Tarcica konstrukcyjna iglasta sortowana metodami wytrzymałościowymi (Construction timber graded by strength methods).

[7] Dzbeński W., Kozakiewicz P., Krzosek S.: Wytrzymałościowe sortowanie tarcicy konstrukcyjnej, Wydawnictwo SGGW, Warszawa 2005.

[8] Dzbeński W., Krzosek S., Kozakiewicz P.: Wtaściwości, metody sortownicze i normalizacja tarcicy budowlanokonstrukcyjnej w programie przedsięwzięć szkoleniowych i wdrożeniowych, „Przemysł Drzewny” 2000, 12, pp. $13-16$.

[9] Szukała R., Szumiński G.: Drewno konstrukcyjne dla budownictwa w świetle aktualnych przepisów, „Rynek Drzewny" 2003, 3, pp. 30-31.

[10] Wdowiak A.: Właściwości strukturalno-wytrzymałościowezginanych belekdrewnianych wzmocnionych kompozytami wtóknistymi (Structural and strength properties of bent wooden beams reinforced with fibrous composites), doctoral dissertation, Kielce University of Technology, Kielce 2018.

[11] Wdowiak A.: Defects in structural timber, "Structure and Environment" 2017, Vol. 9, No. 2, pp. 112-122.

[12] Rudziński L., Wdowiak A.: Strength and structural properties of structural timber, "Structure and Environment" 2016, Vol. 8, No. 2, pp. 103-108.

[13] Wdowiak A.: Using the visual method to sort Polish pine structural sawn timber with respect to strength. Technical Transactions, „Czasopismo Techniczne. Budownictwo” 2016, Issue 2-B, pp. 219-224.

[14] Wdowiak A.: Badanie cech strukturalnych i geometrycznych podczas sortowania wytrzymatościowego tarcicy konstrukcyjnej metoda wizualna (Studying the structural and geometrical features during strength-sorting of structural sawn wood using the visual method), ,Przegląd Budowlany” 2017, Vol. 88, No. 12, pp. 42-46.

[15] Kozakiewicz P., Krzosek S.: Inżynieria materiatów drzewnych, Wydawnictwo SGGW, Warszawa 2013.

[16] Gloss P.: Die maschinelle Sortierung von Schnittholz, Stand der Technik - Vergleich der Verfahren, Holz-Zentralblatt, $13,1982$.

[17] Kozakiewicz P.: Fizyka drewna w teorii i zadaniach. Wybrane zagadnienia, Wydawnictwo SGGW, Warszawa 2003.

[18] PN-EN 1995-1-1:2010 Eurokod 5 Projektowanie konstrukcji drewnianych - Część 1-1: Postanowienia ogólne - Reguły ogólne i reguły dotyczące budynków (Design of wooden structures - Part 1-1: General - provisiobs General and building rules).

[19] PN-EN 1995-1-1:2010/NA:2010 Eurokod 5 Projektowanie konstrukcji drewnianych - Część 1-1: Postanowienia ogólne - Reguły ogólne i reguły dotyczące budynków (Design of wooden structures - Part 1-1: General - provisions - General and building rules). 
[20] PN-EN 1310:2000 Drewno okragłe i tarcica - Metody pomiaru cech (Round wood and timber - Methods of measuring characteristics).

[21] PN-EN 1311:2000 Drewno okrągłe i tarcica - Metody pomiaru biologicznej degradacji (Methods for measuring biological degradation).

[22] Krzysik F.: Nauka o drewnie (Wood Science), Państwowe Wydawnictwo Naukowe, Warszawa 1975.

[23] Wdowiak A., Kroner A.: Wptyw niejednorodności struktury zginanych belek z drewna klejonego na efekt ich wzmocnienia, „Materiały Budowlane” 2017, 1, pp. 87-89.

[24] Adell Almazan F.J., Hermoso Prieto E., Arriaga Martiteguti F., Richter C.: Comparison of the Spanish Visual strength trading standard for structural sawn timber (UNE 56544) with the German one (DIN 4074) for Scots pine (Pinus sylvestris L.) from Germany, Holz Roh Werks, 2008 6, pp. 253-258.

[25] Krzosek S., Grześkiewicz M.: Strength grading Polish-grown Pinus Silvestris L. structural timber using Timber Grader MTG and visual method, "Annals of Warsaw University of Life Sciences - SGGW. Forestry and Wood Technology" 2008, No. 66, pp. 26-31.

\section{Acknowledgments:}

The work was financed by Kielce University of Technology.

\section{Podziękowania:}

Praca była finansowana przez Politechnikę Świętokrzyska, Wydziat Budownictwa i Architektury. 